Јелена Пухар*

Универзитет у Београду

Филолошки факултет
371.3::811.134.2'243

https://doi.org/10.18485/zivjez.2020.40.1.6 Оригинални научни рад

\title{
ИНФИНИТИВНЕ ПРИЛОШКЕ ФИНАЛНЕ КОНСТРУКЦИЈЕ ОБАВЕЗНЕ КОНТРОЛЕ У ИТАЛИЈАНСКОМ ЈЕЗИКУ
}

Циљ овога рада је да, у теоријском оквиру генеративне граматике, испитамо које се подврсте обавезне контроле јављају у инфинитивним прилошким финалним конструкцијама у италијанском језику, да анализирамо семантичку вредност фонетски неисказаног субјекта инфинитивних конструкција (PRO), као и да размотримо у којим условима се подударају морфолошка и семантичка вредност контролисаног елемента. Наше истраживање, у којем користимо метод анализе садржаја, показује да се у инфинитивним прилошким финалним конструкцијама у италијанском језику могу јавити потпуна, делимична и подељена контрола и да се морфолошка и семантичка вредност фонетски нереализованог субјекта у конструкцијама потпуне и подељене контроле подударају.

Кључне речи: инфинитивне прилошке финалне конструкције, обавезна контрола, PRO, италијански језик.

\section{Увод}

Контролни механизми у прилошким реченицама нису били чест предмет истраживања у генеративистичкој литератури до деведесетих година двадесетог века, првенствено због тога што су лингвисти сматрали да контролни механизми у допунским и прилошким реченицама имају исте особине (в. Чомски 1981). Касније су проучавани на примерима из енглеског (Хорнштајн 1999; Ландау 2000, 2013; Грин 2018,

* jelenapuhar@yahoo.com 
2019), италијанског (Ските и сарадници 2001; Донати 2008), турског (Одед 2011), португалског (Нунес 2014) и шпанског језика (Вандајн 2020), при чему је посебна пажња била усмерена на разлике између обавезне и необавезне контроле.

Обавезна контрола, која захтева присуство контролора у управној реченици, може бити потпуна (exhaustive), делимична (partial) или подељена (split). У конструкцијама потпуне контроле фонетски неисказани субјекат је истоветан свом контролору који га у потпуности контролише (Ландау 1999: 12), у конструкцијама делимичне контроле контролор је, поред субјекта или објекта управне реченице, и имплицитна заменица pro $^{1}$ (Родригес 2007: 220), а у конструкцијама подељене контроле субјекат и објекат управне реченице заједно контролишу имплицитни субјекат инфинитивних конструкција (PRO) (Ландау 1999: 12). За разлику од конструкција обавезне контроле, у конструкцијама необавезне контроле контролор имплицитног субјекта зависних конструкција не налази се у реченици која је надређена зависној конструкцији (Ландау 2000: 3).

У овоме раду бавићемо се инфинитивним прилошким финалним конструкцијама обавезне контроле у италијанском језику. У досадашњим истраживањима у италијанском језику објашњене су само инфинитивне прилошке финалне конструкције обавезне потпуне субјекатске контроле (Ските и сарадници 2001; Донати 2008). Стога је циљ овога рада да истражимо које се подврсте обавезне контроле, осим обавезне потпуне субјекатске контроле, јављају у таквим конструкцијама и да утврдимо могуће семантичке вредности имплицитног субјекта зависних конструкција. Примере за ово истраживање преузећемо из корпуса Корис $(\text { Coris })^{2}$, који садржи сто педесет милиона речи, и из италијанских штампаних и електронских медија. Деривацију инфинитивне прилошке

1 Празном категоријом pro означили смо фонетски неисказану заменицу у саставу вишечланог имплицитног субјекта инфинитивних конструкција делимичне контроле (в. Родригес 2007: 220).

2 http://corpora.dslo.unibo.it/TCORIS/ 
финалне конструкције приказаћемо на примеру из наше грађе следећи теорију померања, према којој је имплицитни субјекат инфинитивних конструкција траг померања контролора из зависне реченице у управну реченицу (в. Хорнштајн 1999, 2003).

Прилошке финалне реченице модификују садржај управне реченице, исказујући циљ, сврху и намеру према којима је усмерена радња управне реченице (Гариљано 2003: 583; Шмитке-Боде 2009: 1). Финална веза између управне и инфинитивне реченице може се остварити једнолексемским комплементизатором per (1) или вишелексемским комплементизаторима, који садрже именичке лексеме финалне семантике (нпр. al fine di, allo scopo di, con l'intenzione di, con il desiderio di) $(2,3)$.

(1) Alcuni datori di lavoro useranno i dati genetici per selezionare i potenziali dipendenti.

(Coris: PRACCVolumi)

'Неки послодавци ће употребити генетске податке како би изабрали потенцијалне раднике.'

(2) Si recò in America con l'intenzione di fondare con i proventi degli spettacoli un teatro.

(Coris: MISCVolumi)

'Упутио се у Америку с намером да од прихода позоришних представа оснује позориште.'

(3) Napoleone Bonaparte [...] iniziò la campagna il 10 aprile 1796 con lo scopo di allontanare l'Austria dall'Italia. (Coris: PRACCVolumi)

'Наполеон Бонапарта [...] започео је кампању 10. априла 1796. са циљем да удаљи Аустрију од Италије.'

\section{Инфинитивне прилошке финалне конструкције потпуне контроле}

У зависности од аргумента који контролише фонетски нереализовани субјекат инфинитивних конструкција, потпуна контрола може бити субјекатска или објекатска. У 
конструкцијама потпуне субјекатске контроле контролор је субјекат управне реченице, а у конструкцијама обавезне објекатске контроле контролор је прави или неправи објекат управне реченице. Ските са сарадницима (2001) и Донати (2008), као што смо поменули у Уводу, наводе само примере инфинитивних прилошких финалних конструкција обавезне потпуне субјекатске контроле ${ }^{3}$ :

(4) Gianni arriva sempre in anticipo per parlare di Mario.

'Ђани увек стиже раније да би говорио о Марију.'

(5) Filù guarda la luna per studiare le sue proprietà.

'Филу посматра Месец да би проучила његове особине.'

Међутим, примери из наше грађе показују да контролори прилошких финалних конструкција, поред субјекта (6), могу бити прави (7) или неправи објекат (8).

(6) pro si sedette al tavolo della cucina, con l'intento di PRO lavorare

седе за кухињски сто,

COMP радити-PRES.INF

un po'. (Coris: MON2011_13)

мало.

'Седе за кухињски сто, с намером да мало ради.'

(7) $\mathrm{Mi}$ ha mandato per PRO annunziare ai poveri Me-ACC.1SG послао је COMP објавити-PRES.INF сиромашнима

un lieto messaggio. (Coris: EPHEMOpuscoli)

радосну поруку.

'Послао ме је да објавим сиромашнима радосну поруку.'

(8) Vittoria dimostra disinteresse per la galleria che il padre Виторија показује незаинтересованост за галерију коју отац le aveva regalato per PRO esporre joj-DAT.3SG поклонио је COMP излагати-PRES.INF i suoi quadri. (Coris: MON2008_10) своје слике.

3 Пример (4) преузет је из Ските и сарадници (2001: 496). Пример (5) преузет је из Донати (2008: 202, 203). 
'Виторија показује незаинтересованост за галерију коју јој је отац поклонио да би излагала своје слике.'

На основу наведених примера уочава се да инфинитивне прилошке финалне конструкције потпуне контроле може увести једнолексемски $(7,8)$ или вишелексемски (6) комплементизатор. Контролор имплицитног субјекта зависних реченица може бити детерминативна фраза (7, 8) или празна категорија pro ${ }^{4}$ (6). Из наших примера може се видети да у инфинитивним прилошким финалним конструкцијама потпуне објекатске контроле контролор има обележје аниматности $(+)(7,8)$. У контролним структурама у којима објекат управне реченице носи обележје аниматности $(-)(9,10)$, контролор имплицитног субјекта зависне реченице је субјекат управне реченице.

(9) Ho mandato una email per PRO segnalare Послао сам имејл COMP указати-PRES.INF un errore del telefono. (La Nazione 1.10.2020) грешку телефона.

'Послао сам имејл даукажем на грешку која се тиче телефона.' (10)Oliver hascelto Villa Petrolo per PRO presentare Оливер је изабрао ВилуПетроло СОМР представитиPRES.INF

il suo ultimo libro. (Il Giorno 23.9.2020) своју нову књигу.

'Оливер је изабрао Вилу Петроло за представљање своје нове књиге.'

4 Празну категорију pro користимо за означавање фонетски неисказаног субјекта финитних реченица. 


\section{Инфинитивне прилошке финалне конструкције делимичне контроле}

Инфинитивне прилошке конструкције делимичне контроле садрже реципрочне глаголе ${ }^{5}$, који захтевају учешће у радњи двају или више учесника, те је фонетски неисказани субјекат таквих конструкција семантички увек у множини. PRO је вишечлан синтаксички елемент који се састоји од делимичног контролора (аргумента управне реченице) и од имплицитне заменице pro (Родригес 2007: 220). Морфолошки, скривени субјекат није увек у множини јер се његова морфолошка обележја подударају само са морфолошким обележјем његовог делимичног контролора. У множини је када је и његов делимични контролор у множини.

Могуће семантичке вредности имплицитног субјекта у прилошким финалним конструкцијама делимичне контроле приказаћемо посредством реконструисаних примера из наше грађе, којима ћемо додати имплицитну заменицу pro.

Фонетски нереализовани субјекат семантички може бити у првом лицу множине када је један његов елемент (делимични контролор $(11,12))$ или имплицитна заменица pro $(13)$ у првом лицу једнине или множине.

5 Успостављање делимичне контроле омогућавају реципрочни глаголи, који се могу разврстати у неколико семантичких група. Могу бити глаголи говорења (нпр. chiacchierare 'ћаскати', conversare 'разговарати', dibattere 'дебатовати', discutere 'дискутовати', litigare 'свађати се', parlare 'разговарати', polemizzare 'препирати се'), глаголи сукобљавања (нпр. battersi 'борити се', combattersi 'борити се', lottare 'борити се', scontrarsi 'сукобити ce', picchiarsi 'тући ce'), глаголи слагања и постизања договора (нпр. convenire 'сложити се', patteggiare 'нагодити ce', rappacificarsi 'помирити ce', riconciliarsi 'помирити се'), глаголи удруживања (нпр. affratellarsi 'збратимити се', allearsi 'удружити ce', apparentarsi 'ородити ce', coalizzarsi 'удружити се'), глаголи такмичарског надметања (нпр. competere 'такмичити ce', gareggiare 'надметати се'), глаголи окупљања (нпр. adunarsi 'окупити ce', radunarsi 'састати се'), глаголи сусретања (нпр. incontrarsi 'срести се', vedersi 'виђати се')... 
(11)Vado a Roma per PR01PL negoziare. (Metro 25.9.2020) 'Идем у Рим да преговарам.'

PRO = io + tu / lui / lei / Lei / voi / loro (PRO = ja + ти / он / она / Ви / ви / они / оне')

(12)Andiamo a Roma per PR01PL negoziare.

'Идемо у Рим да преговарамо.'

PRO = noi + tu / lui / lei / Lei / voi / loro (PRO = 'ми + ти / он / она / Ви / ви / они / оне')

(13)*Sergio e Luisella erano andati a fare un viaggio in Grecia per PR01PL riconciliarsi. ${ }^{6}$

(Coris: STAMPAQuotidiani)

'Серђо и Луизела су отпутовали у Грчку да би се помирили.' PRO $=$ Sergio e Luisella + io $/$ noi $($ PRO $=$ 'Серђо и Луизела + ја / ми')

Имплицитни субјекат инфинитивних конструкција семантички може бити у другом лицу множине када подразумева групу којој припадају саговорник или саговорници. Такву семантичку вредност PRO може имати: а) уколико је његов делимични контролор у другом лицу једнине или множине, а имплицитна заменица у трећем лицу једнине или множине $(14,15)$, б) ако је његов делимични контролор хонорифичка заменичка форма у трећем лицу једнине, а имплицитна заменица у трећем лицу једнине или

6 Уколико би се имплицитни субјекат инфинитивне конструкције per PRO riconciliarsi ('да би се помирили') тумачио као субјекат са семантичком вредношћу првог лица множине, пример (13) био би неграматичан. Наиме, будући да управна реченица садржи деиктички глагол andare ('отићи'), који се употребљава када се говорник или саговорник не налазе на месту које је циљ кретања субјекта у трећем лицу једнине или множине (Ванели 2001: 279, 280), PRO у зависној конструкцији не укључује говорника или групу говорника. Ако би се, уместо глагола andare ('отићи'), у управној реченици употребио деиктички глагол venire ('доћи'), који се користи када се говорник или саговорник налазе на месту које представља циљ кретања субјекта у трећем лицу једнине или множине (Ванели 2001: $280)$, контролна структура са имплицитним субјектом са семантичком вредношћу првог лица множине била би граматична (уп. Sergio e Luisella erano venuti in Grecia per PR01PL riconciliarsi. 'Серђо и Луизела су дошли у Грчку да би се помирили.') 
множине (16), в) када поред делимичног контролора у трећем лицу једнине или множине укључује и имплицитну заменицу у другом лицу једнине или множине или хонорифичку заменичку форму у трећем лицу једнине $(17,18)$.

(14)Vieni a Torino per PRO2PL riconciliarti. (Metro 28.9.2020) 'Долазиш у Торино да се помириш.' PRO = tu + lui / lei / loro (PRO = 'ти + он / она / они / оне')

(15)Venite a Torino per PRO2PL riconciliarvi.

'Долазите у Торино да се помирите.'

PRO = voi + lui / lei / loro (PRO = 'ви + он / она / они / оне')

(16)Viene a Torino per PRO2PL riconciliarsi.

'Долазите у Торино да се помирите.'

PRO = Lei + lui / lei / loro (PRO = 'Ви + он / она / они / оне')

(17)Viene a Torino per PRO2PL riconciliarsi.

'Долази у Торино да се помири.'

PRO = lui / lei + tu / Lei / voi (PRO = 'он / она + ти / Ви / ви')

(18)Vengono a Torino per PRO2PL riconciliarsi.

'Долазе у Торино да се помире.'

PRO = loro + tu / Lei / voi (PRO = 'они / оне + ти / Ви / ви')

PRO може бити семантички у трећем лицу множине када

су оба члана синтаксички сложеног фонетски неисказаног субјекта у трећем лицу једнине или множине.

(19)Paolo era andato a Milano per PRO3PL accordarsi. (Metro 28.9.2020)

'Паоло је отишао у Милано да се договори.'

PRO = Paolo + lui / lei / loro (PRO = 'Паоло + он / она / они / оне')

(20)Paolo e Luisa erano andati a Milano per PRO3PL accordarsi.

'Паоло и Луиза су отишли у Милано да се договоре.'

PRO = Paolo e Luisa + lui $/$ lei / loro (PRO = 'Паоло и Луиза + он / она / они / оне')

Клитике узајамно-повратних глагола показују да се, када је делимични контролор у једнини, морфолошко и семантичко лице имплицитног субјекта не подударају. Морфолошко лице скривеног субјекта је истоветно морфолошком лицу делимичног контролора, нпр: 
(21)Vieni a Torino per PRO riconciliarti. доћи-PRES.2SG у Торино COMP помирити-PRES.INF ce-REFL.2SG

'Долазиш у Торино да се помириш.'

Мишљења смо да се контролне структуре са контролором у множини могу анализирати и као конструкције обавезнепотпуне субјекатске контроле ако се имплицитни субјекат тумачи као контролисани елемент који се морфолошки и семантички подудара са субјектом управне реченице, као у примеру:

(22)[Loro]i vengono

a Torino per PROi riconciliarsi.

[Они] доћи-PRES.3PL у Торино COMP помирити-

PRES.INF ce-REFL.3PL

'[Они] долазе у Торино да се помире.'

\section{Инфинитивне прилошке финалне конструкције подељене контроле}

У конструкцијама подељене контроле два аргумента управне реченице заједно контролишу фонетски неисказани субјекат инфинитивне реченице (Ландау 1999: 12). Контролори конструкција подељене контроле, поред субјекта, могу бити и прави (23) или неправи (24) објекат.

(23)Lo

chiamerà

per

PRO3PL accordarsi

га-ACC.3SG позваће COMP договорити-PRES.

INF ce-REFL.3PL

sul nuovo orario. (Metro 23.9.2020)

о новом распореду.

'Позваће га да се договоре о новом распореду.'

(24)Mi telefonò per PR01PL incontrarci.

(CorisMON2005_07)

ми-DAT.1SG телефонирао је COMP састати-PRES.

INF ce-REFL.1PL

'Телефонирао ми је да бисмо се састали.' 
Будући да инфинитивне конструкције подељене контроле имају два контролора, њихов имплицитни субјекат семантички је увек у множини (Фуџи 2010: 3). Наша анализа је показала да се у конструкцијама подељене контроле морфолошка и семантичка вредност имплицитног субјекта подударају, те је имплицитни субјекат и морфолошки увек у множини, што потврђују клитике повратних глагола (уп. 23, 24).

Реконструисаним примерима из нашег корпуса приказаћемо могуће морфолошке и семантичке вредности имплицитног субјектау инфинитивним прилошким финалним конструкцијама подељене контроле.

Као што показују примери $(25,26)$, PRO је, без обзира на лице објекта управне реченице, морфолошки и семантички у првом лицу множине када је субјекат управне реченице у првом лицу једнине или множине.

(25)Ti / gli / le / Le / vi / gli telefonerò per PR01PL incontrarci.

'Телефонираћу ти / му / јој / Вам / вам / им да бисмо се састали.'

PRO = ti / gli / le / Le / vi / gli + io (PRO = 'mu / мy / joj / Bam / вам / им + ја')

(26)Ti / gli / le / Le / vi / gli telefoneremo per PR01PL incontrarci. 'Телефонираћемо ти / му / јој / Вам / вам / им да бисмо се састали.'

PRO = ti / gli / le / Le / vi / gli + noi (PRO = 'ти / мy / joj / Вaм / вам / им + ми')

Фонетски неисказани субјекат је у првом лицу множине и када је објекат управне реченице у првом лицу једнине или множине, без обзира на лице субјекта.

(27)Mi chiamerai / chiamerà / chiamerete / chiameranno per PR01PL consultarci.

'Позваћеш / позваће / позваћете / позваће ме да бисмо се консултовали.'

$\mathrm{PRO}=\mathrm{mi}+$ tu $/$ lui $/$ lei $/$ Lei $/$ voi / loro $(\mathrm{PRO}=$ ' ме + ти $/$ он $/$ она / Ви / ви / они / оне') 
(28)Ci chiamerai / chiamerà / chiamerete / chiameranno per PR01PL consultarci.

ППозваћеш / позваће / позваћете / позваће нас да бисмо се консултовали.'

PRO = ci + tu / lui / lei / Lei / voi / loro (PRO = 'нас + ти / он / она / Ви / ви / они / оне')

Ако је субјекат управне реченице у другом лицу једнине или множине, а објекат у трећем лицу једнине или множине, имплицитни субјекат је семантички и морфолошки у другом лицу множине.

(29)Gli / le / gli scriverai per PRO2PL riconciliarvi. (Metro 23.9.2020)

'Писаћеш му / јој / им да бисте се помирили.'

PRO = gli / le / gli + tu (PRO = 'мy / joj / им + ти')

(30)Gli / le / gli scriverete per PRO2PL riconciliarvi.

'Писаћете му / јој / им да бисте се помирили.'

$\mathrm{PRO}=$ gli $/$ le $/$ gli + voi $(\mathrm{PRO}=$ 'му / joj / им + ви')

PRO је морфолошки и семантички у другом лицу множине и када је објекат у другом лицу једнине или множине, а субјекат у трећем лицу једнине или множине.

(31)Ti / vi scriverà per PRO2PL riconciliarvi.

'Писаће ти / вам да бисте се помирили.'

PRO = ti / vi + lui / lei (PRO = 'ти / вам + он / она')

(32)Ti / vi scriveranno per PRO2PL riconciliarvi.

'Писаће ти / вам да бисте се помирили.'

$\mathrm{PRO}=\mathrm{ti} / \mathrm{vi}+$ loro $(\mathrm{PRO}=$ 'ти / вам + они / оне')

Фонетски неисказани субјекат инфинитивних конструкција је семантички и морфолошки у трећем лицу множине када су субјекат и објекат управне реченице у трећем лицу једнине или множине.

(33)Lo / la / li / le contatterà per PRO3PL accordarsi. (La Nazione 1.10.2020)

'Позваће га / је / их да би се договорили.'

PRO = lo / la / li / le + lui / lei (PRO = 'га / је / их + он / она' $)$ 
(34)Lo / la / li / le contatteranno per PRO3PL accordarsi. 'Позваће га / је / их да би се договорили.'

PRO = lo $/$ la $/$ li $/$ le + loro (PRO = 'га $/$ je / их + они / оне' $)$

\section{Деривација инфинитивне прилошке финалне конструкције обавезне контроле}

Будући да због ограниченог простора у раду не можемо да прикажемо деривацију инфинитивних прилошких финалних конструкција свих подврста обавезне контроле, на примеру деривације конструкције потпуне контроле, која се најчешће остварује у инфинитивним прилошким финалним конструкцијама, показаћемо да се приликом приказивања такве деривације и на инфинитивне конструкције у италијанском језику може применити Хорнштајнова теорија померања, којом се, према Грину (2019: 28), за разлику од других теорија контроле, могу објаснити све инфинитивне прилошке конструкције обавезне и необавезне контроле. Контролну структуру La loro amica Martina apre il giornale per leggere le ultime notizie ('Њихова пријатељица Мартина отвара новине да прочита последње вести'), преузету из нашег корпуса, представићемо синтаксичким стаблима, која су један од најбољих визуелних начина приказивања синтаксичких структура (Јул 2017: 128).

Према теорији померања (Хорнштајн 1999), контролне структуре које садрже прилошке реченице настају спајањем два одвојена синтаксичка стабла. Прво се генерише зависна реченица, а потом управна реченица. Дакле, пре копирања контролора из зависне у управну реченицу, у засебним деривацијама настају прилошка финална реченица per < la loro amica Martina > leggere le ultime notizie и управна реченица apre il giornale, које међусобно још увек нису повезане. 

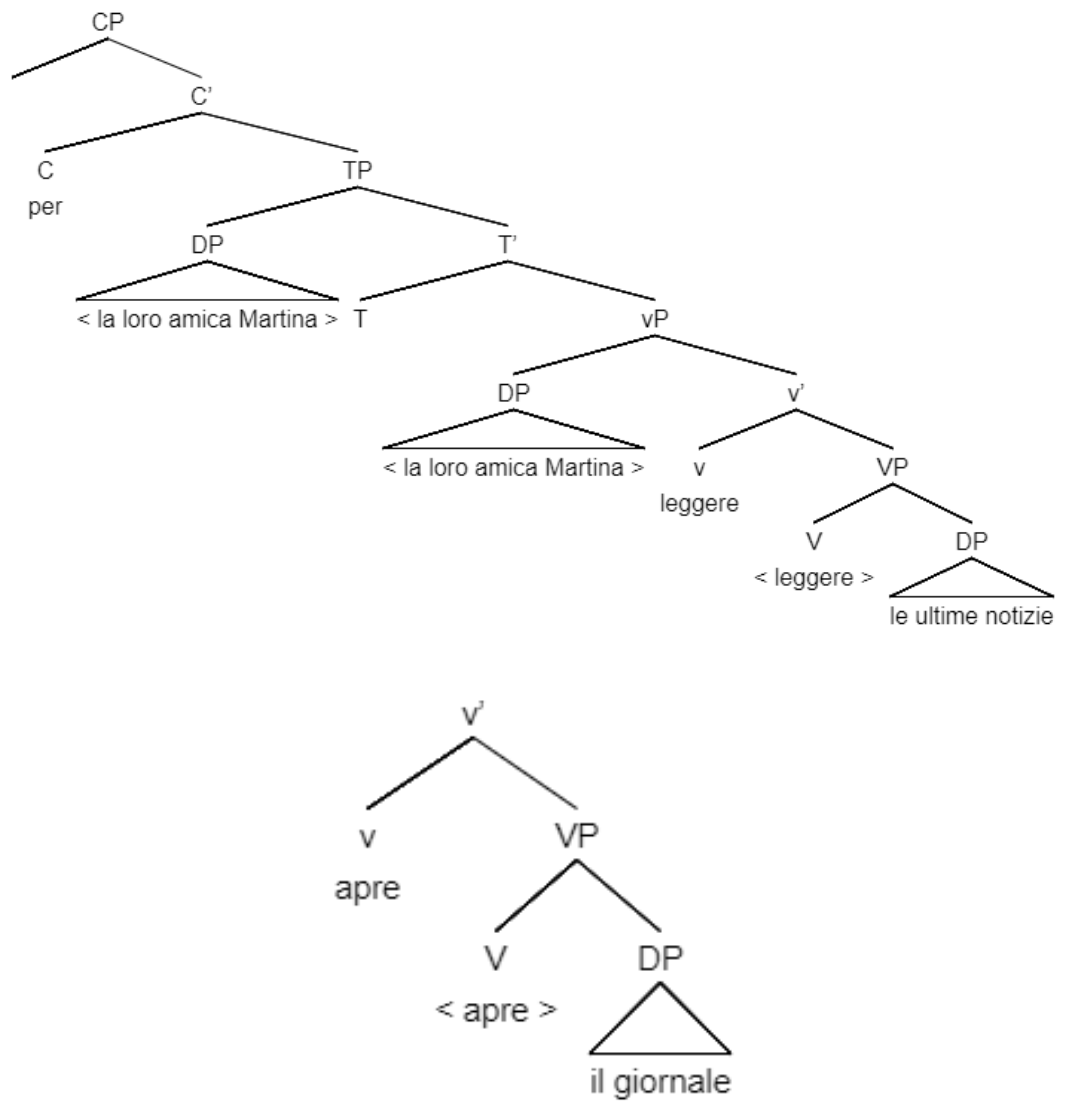

Пре спајања синтаксичких стабала, да би се проверило Ө-обележје ${ }^{7}$ глагола управне реченице apre, детерминативна фраза la loro amica се копира и помера из зависне реченице на позицију Spec, vP управне реченице. Овакво померање у генеративистичкој литератури назива се померање у страну (sideward movement) (Нунес 2001). На тој позицији детерминативна фраза добија семантичку улогу агенса.

7 Хорнштајн (1999: 78, 79) сматра да су семантичке улоге синтаксичка обележја глагола. 


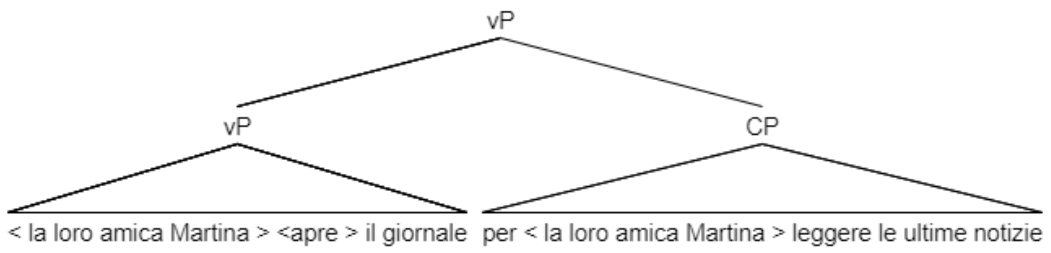

У следећој тачки деривације са глаголском фразом vP спаја се Т и настаје Т'. Детерминативна фраза la loro amica Martina ca позиције Spec, vP помера се на позицију Spec, TP, где проверава обележје принципа проширене пројекције категорије Т. На крају деривације бришу се све ниже копије детерминативне фразе la loro amica Martina.

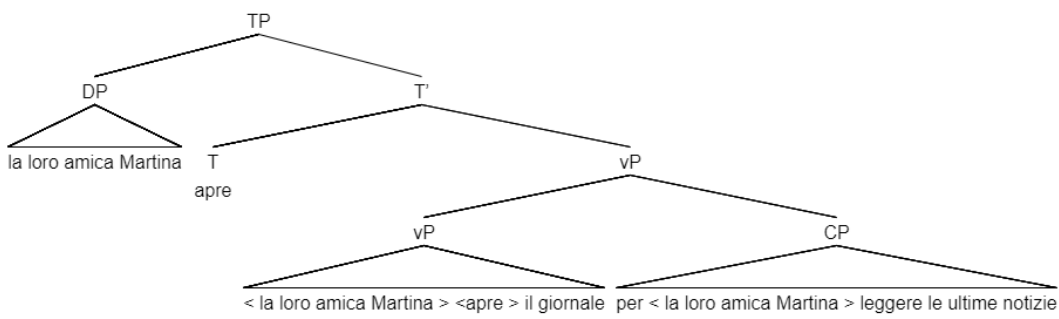

\section{Закључак}

На основу испитаних примера из нашег корпуса закључујемо да се у инфинитивним прилошким финалним конструкцијама у италијанском језику јављају све три подврсте обавезне контроле. Наше истраживање је показало да се у прилошким финалним конструкцијама потпуне и подељене контроле вредност морфолошког и семантичког лица имплицитног субјекта подудара. Установили смо да се у прилошким финалним конструкцијама делимичне контроле морфолошко лице фонетски неисказаног субјекта подудара са морфолошким лицем делимичног контролора, али и да се његова семантичка вредност 
разликује од семантичке вредности његовог делимичног контролора јер је условљена вредностима чланова синтаксички вишечланог субјекта. На примеру контролне структуре La loro amica Martina apre il giornale per leggere le ultime notizie ('Њихова пријатељица Мартина отвара новине да прочита последње вести') приказали смо да се и надеривацију контролних структура у италијанском језику може применити Хорнштајнова теорија померања. У италијанском језику се, поред инфинитивних прилошких финалних конструкција обавезне контроле, јављају и инфинитивне прилошке финалне конструкције необавезне контроле (нпр. Ad essere onesto, non lo ricordo molto ${ }^{8}$. (Coris: MON2005_07) 'Да будем искрен, не сећам га се много.'), па би инфинитивне прилошке финалне конструкције необавезне контроле могле бити предмет наших даљих истраживања.

8 Ad PRO essere onesto, non lo ricordo molto. COMP бити-PRES.INF. искрен, не га сећам се много. 'Да будем искрен, не сећам га се много.' 


\section{ЛИТЕРАТУРА}

\section{Извори}

CORIS - Corpus dell'italiano scritto. Facoltà di Lettere e Filosofia, Università di Bologna, Bologna. Online, [http://corpora.dslo.unibo.it/TCORIS/] Il Giorno, Milano: Monrif Group, [23.9.2020]

La Nazione, Firenze: RCS MediaGroup. Online, [https://www.lanazione. it/], [1.10.2020]

Metro, Roma: New Media Enterprise, [23.9.2020; 25.9.2020; 28.9.2020]

\section{Референце}

Вандајн 2020: K. VanDyne, The interaction of parasitic gaps and adjunct control in Spanish. In: J. J. Colomina-Almiñana, S. Sessarego (eds.), Language patterns in Spanish and beyond, London: Routledge, 37-52.

Ванели 2001: L. Vanelli, La deissi. In: L. Renzi et al. (eds.), Grande grammatica italiana di consultazione, III. Tipi di frase, deissi, formazione delle parole, Bologna: Il Mulino, 279, 280.

Гариљано 2003: P. Garigliano, Sintassi della lingua italiana. Catania: CUECM. Грин 2018: J. J. Green, Adjunct control: Syntax and processing. College Park, MD: University of Maryland. Online, [http://dx.doi.org/10.13016/ M2HX15V08]

Грин 2019: J. J. Green, A movement theory of adjunct control. Glossa, 4(1), 87. Online, [https://www.glossa-journal.org/articles/10.5334/gjgl.724/] Донати 2008: C. Donati, La sintassi. Bologna: Il Mulino.

Јул 2017: G. Yule, Introduzione alla linguistica. Bologna: Il Mulino.

Ландау 1999: I. Landau, Elements of control. Unpublished doctoral dissertation. Tel Aviv: Tel Aviv University.

Ландау 2000: I. Landau, Elements of control. Structure and meaning in infinitival constructions. Berlin: Springer.

Ландау 2013: I. Landau, Control in generative grammar, Cambridge: CUP. Нунес 2001: J. Nunes, Sideward movement. Linguistic Inquiry, 32(2), 303-344. Нунес 2014: J. Nunes, Adjunct control and edge features. In: P. Kosta et al. (eds.), Minimalism and beyond: Radicalizing the interfaces, Amsterdam: John Benjamins, 79-108.

Одед 2011: I. Oded, Recalculating adjunct control. Unpublished doctoral dissertation. College Park, MD: University of Maryland. Online, [https://drum.lib.umd.edu/handle/1903/11979] 
Родригес 2007: C. Rodrigues, Agreement and flotation in partial and inverse partial control configurations. In: W. D. Davies, S. Dubinsky (eds.), New horizons in the analysis of control and raising, Dordrecht: Springer, 213-229.

Ските и сарадници 2001: G. Skytte et al., Frasi subordinate all'infinito. In: L. Renzi et al. (eds.), Grande grammatica italiana di consultazione, II. I sintagmi verbale, aggettivale, avverbiale. La subordinazione, Bologna: Il Mulino, 496.

Фуџи 2010: T. Fujii, Split control and the principle of minimal distance. In: N. Hornstein, M. Polinsky (eds.), Movement theory of control, Amsterdam: John Benjamins, 211-244.

Хорнштајн 1999: N. Hornstein, Movement and control. Linguistic Inquiry, $30(1), 69-96$.

Хорнштајн 2003: N. Hornstein, On control. In: R. Hendrick (ed.), Minimalist Syntax, Oxford: Blackwell, 6-81.

Чомски 1981: N. Chomsky, Lectures on government and binding. Dordrecht: Foris.

Шмитке-Боде 2009: К. Schmidtke-Bode, A Typology of Purpose Clauses. Amsterdam: John Benjamins Publishing Company. 


\section{Jelena Puhar}

\section{COSTRUTTI INFINITIVI AVVERBIALI FINALI A CONTROLLO OBBLIGATORIO IN LINGUA ITALIANA}

\section{Riassunto}

Il presente contributo intende sondare, nell'ambito della grammatica generativa, i tipi di controllo obbligatorio nei construtti infinitivi avverbiali finali in lingua italiana. In base all'analisi effettuata su esempi presi dal corpus Coris nonché su quelli presi dai media italiani elettronici e cartacei possiamo concludere che il controllo obbligatorio nei costrutti infinitivi avverbiali finali può essere completo, parziale o diviso. Nei casi di controllo completo e diviso il valore semantico e morfologico del soggetto silente (PRO) è identico. Nei contesti di controllo parziale semanticamente PRO è sempre al plurale mentre morfologicamente può essere al singolare quando il suo controllore parziale è al singolare.

Parole chiave: costrutti infinitivi avverbiali finali, controllo obbligatorio, PRO, lingua italiana. 